\title{
Relationship of Plant Growth and Actual Evapotranspiration to Irrigation Frequency Based on Management Allowed Deficits for Container Nursery Stock
}

\author{
R.C. Beeson, Jr. \\ University of Florida, Institute of Food and Agricultural Sciences, Mid-Florida Research and Education \\ Center-Apopka, 2725 S. Binion Road, Apopka, FL 32703
}

ADDiTIONAL INDEX WORDS. container production, water requirements, woody ornamentals

\begin{abstract}
Three species of woody ornamentals, Viburnum odoratissimum Ker Gawl, Ligustrum japonicum Thunb., and Rhaphiolepis indica Lindl. were transplanted from 3.8-L into 11.4-L containers and grown for 6 months while irrigated with overhead sprinkler irrigation. Irrigation regimes imposed consisted of an 18-mm-daily control and irrigation to saturation based on $20 \%, 40 \%, 60 \%$, and $80 \%$ deficits in plant available water [management allowed deficits (MAD)]. Based on different evaluation methods, recommendations of $20 \%, 20 \%$, and $40 \%$ MAD are supported for $V$. odoratissimum, $L$. japonica, and $R$. indica, respectively, for commercial production. Comparisons of plant growth rates, supplied water, and conversion of transpiration to shoot biomass are discussed among irrigation regimes within each species. Comparisons of cumulative actual evapotranspiration $\left(\mathrm{ET}_{\mathrm{A}}\right)$ to either shoot dry mass or canopy volume were linear and highly correlated. Results indicated there were minimum cumulative $\mathbf{E T}_{\mathrm{A}}$ volumes required for plants to obtain a specific size. This suggests that irrigation regimes that restrict daily $\mathbf{E T}_{\mathrm{A}}$ will prolong production times and may increase supplemental irrigation requirements. Thus the hypothesis that restrictive irrigation regimes will reduce irrigation requirements to produce container plants is false due to the strong relationship between cumulative $\mathbf{E T}_{\mathrm{A}}$ and plant size.
\end{abstract}

The direct linkage between plant productivity (mass accumulation) and soil water availability and plant transpiration has been recognized since the early 1900s (Arkley, 1963). Maximum productivity occurs when soil water is maintained near field capacity in a wide range of species (Arkley, 1963; Halevy, 1972). This also occurs for container-grown woody ornamental shrub species (Beeson, 1992), and for trees cyclically irrigated in 11.3L containers (Beeson and Haydu, 1995). Maintaining high soil moisture or cyclic irrigation has increased productivity for many additional ornamental species (Ruter, 1998; Timmer and Armstrong, 1989, Tyler et al., 1996; Whitesides, 1989). In addition, Keever and Cobb (1985) reported that container-grown 'Hersey Red' azaleas (Rhododendron xobtusum Planch), overhead irrigated during the early morning and again at mid-day, were larger at the end of the year than their once a morning counterparts. Thus to maximize growth, commercial nurseries should strive to maintain plant available water to near $100 \%$ of container capacity. In large containers, this is readily accomplished with micro-irrigation systems with minimum water waste. However most small containers $(<16 \mathrm{~L})$ are irrigated with overhead sprinkler systems, and most likely will be the next 10 years (Beeson et al., 2004). Usually only $20 \%$ to $40 \%$ of the water applied through these systems is retained in the containers (Weatherspoon and Harrell, 1980; Beeson and Knox, 1991). Thus $60 \%$ to $80 \%$ of overhead irrigated water is of almost no value for plant growth. For these small container-grown shrubs, it was not economically feasible to use micro-irrigation in 1995 (Haydu and Beeson, 1997) and this is likely still true.

Received for publication 18 Feb. 2005. Accepted for publication 12 Sept. 2005. This research was partially supported by a grant from the Southwest Florida Water Management District. This work supported by the Florida Agricultural Experiment Station, and approved for publication as journal series R-10969.
In several regions with container production, water for irrigation is either limited, restricted, or both (Beeson et al., 2004). Given that maintaining container capacity near $100 \%$ is impractical with overhead sprinkler irrigation as currently used, the question becomes what percentage of container capacity should be maintained for commercially acceptable growth rates. Welsh and Zajicek (1993) investigated the growth response of rooted cuttings of Photinia $\times$ fraseri $\mathrm{L}$. when the container substrate was allowed to dry to preset levels before irrigation, termed "managed allowable deficit." Acceptable growth was observed up to losses of $25 \%$ of available water by evapotranspiration. However when a substrate was allowed to dry to $50 \%$ of available water before irrigation, shoot growth was reduced $15 \%$. In addition to conserving water through reduced irrigation frequencies, use of MAD in outdoor production allows for more effective harvest of rainfall than when container substrates are maintained near container capacity through supplemental irrigation.

In 1993, a research program was initiated to calculate coefficients for woody ornamentals in container production that related plant water use to reference evapotranspiration (ETo). These coefficients were to be used in calculating allocations for ground water withdraw permits for container nurseries in Southwestern Florida. Before beginning this task, it was necessary to determine how frequently to irrigate the plants when determining these coefficients. The experiment presented here evaluated the effect of MAD levels on the growth rate of three woody ornamental shrub species during outdoor production in 11.4-L containers. Maximum acceptable MADs for each species established in this experiment were used to determine irrigation frequency during development of the coefficients. The objective of this experiment was to establish the maximum MAD that produced plants at a commercially acceptable quality and time period. In addition, relationships between actual evapotranspiration and growth of these woody ornamental species were investigated. 


\section{Materials and Methods}

On 28 May 1993, 400 rooted cuttings of Rhaphiolepis indica (indian hawthorn) were transplanted into 3.8-Lblack polyethylene containers (C-650; Lerio Corp., Kissimmee, Fla.). The substrate consisted of $64 \%$ composted pine bark fines (material passing through a $25-\mathrm{mm}$ screen), $27 \%$ Florida sedge peat and $9 \%$ coarse sand amended with $0.86 \mathrm{~kg} \cdot \mathrm{m}^{-3}$ micro-nutrients (Peter's Fritted Trace Elements, Scotts Co., Marysville, Ohio) and $2.9 \mathrm{~kg} \cdot \mathrm{m}^{-3}$ dolomite limestone blended by a commercial vendor (Sunrise Landscape, Apopka, Fla.). On 11 Oct. 1993, 400 rooted cuttings of Viburnum odoratissimum (sweet viburnum) and Ligustrum japonicum (japanese ligustrum) were transplanted in similar containers using the same substrate blend. Transplanting of each species was staggered, based on local experience, so that all species would be at marketable size in the 3.8-L containers at the start of the experiment in 1994. Within 1 week after transplanting, each plant received around $150 \mathrm{~mL}$ of a $21 \mathrm{~mm} \mathrm{~N}$ solution of liquid fertilizer(20N-8.7P-16.5K, Peter's 20-20-20; Scotts Co.) and was treated with $0.33 \mathrm{~g} \cdot \mathrm{m}^{-3}$ a.i. of oxadiazon pre-emergence granular herbicide (Ronstar G; Rhone-Poulenc Ag Co., Research Triangle Park, N.C.). At transplanting, each container of indian hawthorn was top dressed with $12 \mathrm{~g}$ of a $18 \mathrm{~N}-2.6 \mathrm{P}-9.9 \mathrm{~K}$ controlled release fertilizer (8-9 month, Osmocote 18-6-12; Scotts Co.). After transplanting in October, containers of the three species were given 13 $\mathrm{g}$ of a $14 \mathrm{~N}-6 \mathrm{P}-11.6 \mathrm{~K}$ controlled release fertilizer (3-4 month, Osmocote 14-14-14; Scotts Co.). All plants were grown in full sun on a black polyethylene woven ground cloth (VJ Grower's Supply, Apopka, Fla.) under overhead impact sprinkler irrigation (model 1572; Nelson Corp., Peoria, Ill.). Irrigation frequency was daily during the summer, switching to alternate days during late November through mid-March. Application rates ranged from 6.2 to $12.5 \mathrm{~mm}$ per event, depending on plant size. During this period, plants were pruned and pesticides applied as needed to produce commercial quality plants.

On 23-24 Feb. 1994, 325 plants of each species were transplanted into 11.4-L black polyethylene containers (C-350; Lerio Corp.) using newly blended substrate of the same proportions described previously. Based on Australian Standard Methods (Standards Australia, 1989), which uses a 15-cm-tall tube, the substrate averaged (five replications) 27\% air porosity and $41 \%$ water holding capacity, with a total porosity of $68 \%$ based on oven dried mass. Within 1 week after transplanting, each container was top dressed with $50 \mathrm{~g}$ of a $18 \mathrm{~N}-2.6 \mathrm{P}-9.9 \mathrm{~K}$ controlled release fertilizer (Osmocote 18-6-12; Scotts Co.), and treated with 0.33 $\mathrm{g} \cdot \mathrm{m}^{-3}$ a.i. of a blend of $2 \%$ oxyfluorfen and $1 \%$ pendimethalin for pre-emergence weed control (Ornamental Herbicide II; Scotts Co.). Throughout the experiment, plants were pruned as required to promote commercially acceptable quality.

Sixty-five plants of each species were placed with $13 \mathrm{~cm}$ between containers in five randomly assigned pads within the production area. Each pad contained only plants from one species. The production area was $63.4 \times 20 \mathrm{~m}$ and covered with black polyethylene ground cloth (VJ Grower's Supply). It was divided into two rows of eight pads, with $1.9 \mathrm{~m}$ between pads within a row and $4.6 \mathrm{~m}$ between rows. Each pad area was square and $6.15 \mathrm{~m}$ on a side. Two irrigation risers, $1.4 \mathrm{~m}$ in height, were positioned at diagonal corners with partial circle impact sprinklers (model 1572; Nelson Irrigation). Irrigation to each pad was independently controlled with an electric valve followed by a mechanical water meter (model C-700; ABB Water Meters, Ocala, Fla.). Prior to placement of plants on the pads sprinkler heads were adjusted to provide a Christensen coefficient of uniformity of 0.85 or better (Haman et al., 1996) within a rectangular area of $3.7 \times 4.9 \mathrm{~m}$ in the center of each pad. Each pad was established an independent irrigation treatment. Two plants within each pad were each grown in suspension lysimeters.

Reference ET was calculated using a modified Penmen equation (Hargreaves and Samani, 1982) supplied in the Ref-ET software package (Allen, 2000). Required meteorological data for calculation of more recent versions of the Penman-Montieth equation were unavailable. Temperature data was obtained from a registered NOAA (National Oceanic and Atmospheric Adminstration) weather station site at the research station. Net solar radiation was obtained from a LI-190 (LI-COR, Lincoln, Neb.) located on site. Wind speed was recorded on the production area using a wind odometer (Trade Wind Instruments, Enumclaw, Wash.).

Suspension lysimeters were constructed as a tripod, $2.2 \mathrm{~m}$ in height. Attached to the top was a load cell (SSM-50; Interface, Scottsdale, Ariz.) from which a square basket was suspended by small galvanized chains. The bottom of the basket was $\approx 2 \mathrm{~cm}$ above the ground cloth surface. Hence the top of the container in a lysimeter was $\approx 3$ to $5 \mathrm{~cm}$ above that of the surrounding containers. Load cells were connected to a system of multiplexers (AM-32 and AM-416; Campbell Scientific, Logan, Utah) and a data logger (CR-10; Campbell Scientific) that measured and recorded individual mass changes hourly. Within $2 \mathrm{~d}$ after all plants were transplanted, lysimeter plants were submitted to a dry down (no irrigation or rainfall) to determine initial plant available water within each container. Initial mass of saturated containers after 30 min of drainage were recorded. Water was withheld until plants were visually wilted by mid-morning. The number of days between saturation and visible wilt varied somewhat among species and individual plants. Container mass the evening of the day at which this occurred was subtracted from saturated mass to determine plant available water. These values were used to set trigger points for initiating irrigation within each production area.

Moisture deficit treatments (MAD) for each species consisted of initiating irrigation when $20 \%, 40 \%, 60 \%$, or $80 \%$ of the plant available water within a container had been lost through evapotranspiration $\left(\mathrm{ET}_{\mathrm{A}}\right)$. When irrigation was required for a MAD treatment, it was applied only between 0100 and $0500 \mathrm{HR}$. The data logger compared midnight mass of each lysimeter plant to its corresponding trigger mass at which the desired MAD level was reached. When both lysimeter plants on a pad were below their trigger mass at midnight, irrigation was initiated by the data logger through a SDM-CD-16 module (Campbell Scientific). Trigger points were based on the saturated mass of each container, minus the mass change required to obtain the designated MAD level based on each individual container's plant available water. When irrigated, MAD treatments were overhead irrigated until the media was saturated. Based on a preliminary experiment, plants were considered saturated when the average increase in container mass over a 10 -min period was $<10 \mathrm{~g}$. When this occurred during an irrigation cycle, the data logger closed the electric water valve. A fifth irrigation treatment for each species was established as a control. This consisted of applying an 18-mm depth of water to one pad of each species daily, independent of rainfall, using a digital irrigation time clock (RainDial; Hardee Irrigation, Laguna Niguel, Calif.).

A second dry down was initiated in mid-May. By this point, based on visual inspection of removed root balls of nonlysimeter plants, roots had encompassed the 11.4-L container volumes for all species. Further measurements of container available water 
were considered unnecessary. During each dry down, nonlysimeter plants were hand watered as needed. Trigger points were reset in late May based on new determinations of plant available water. Trigger points were adjusted in July to account for increases in container weight due to plant growth. The experiment was completed in early September.

From mass data recorded for each plant, daily $\mathrm{ET}_{\mathrm{A}}$ was calculated for each plant in the lysimeters. In the simplest case, mass at $2200 \mathrm{HR}$ was subtracted from the mass at $0600 \mathrm{HR}$. On rain days, graphs of diurnal mass changes for each lysimeter plant were visually examined and estimates of beginning and ending times of $\mathrm{ET}_{\mathrm{A}}$ were made to exclude rain events, including the period of draining/evaporation of surface rain water from a canopy. $\mathrm{ET}_{\mathrm{A}}$ on rain days was calculated for each lysimeter plant by summing its differences in recorded masses at the beginning and ending of each estimated period of $\mathrm{ET}_{\mathrm{A}}$ for that day. $\mathrm{ET}_{\mathrm{A}}$ for all days for each lysimeter plant was divided by the corresponding ETo, resulting in the calculation of individual plant $\mathrm{ET}_{\mathrm{A}}$ per milliliter ETo values. Comparison of these values on rain days to nonrain days within 4 to $8 \mathrm{~d}$ bracketing the rain day provided a measure of the accuracy of the estimate of the time period influence of the rain event. The number of days within a bracket was dependent on including four nonrain days for comparison. Because changes in leaf area and other nonclimatic factors during these brief 4to 8 -d periods were insignificant, differences in milliliters per millimeter ETo values for each lysimeter plant between rain and nonrain days were due to inaccurate estimates of the influence of the rain event. The estimate of the time period of influence of the rain event was then broadened or narrowed for the day in question until the milliliters $\mathrm{ET}_{\mathrm{A}}$ per millimeter ETo value was comparable to the range of these values within the bracketed time period. Corrected $\mathrm{ET}_{\mathrm{A}}$ was summed over the production period for each lysimeter plant to obtain cumulative $\mathrm{ET}_{\mathrm{A}}$.

Irrigation volumes applied were recorded for each pad Monday through Friday. Canopy dimensions of widest width, width perpendicular to the widest width and average canopy height were recorded for each lysimeter plant initially, and every 4 weeks after transplanting into the 11.4-Lcontainers. Canopy dimensions were multiplied to calculate a growth index [GI = width $1 \times$ width 2 $\times$ height (cubic meters)], which estimated canopy volume, and projected canopy surface area [width $\times$ width (square meters)].

On 25 Aug. 1994, a field day was held to receive input from the Florida nursery industry as to commercially acceptable growth rates. Participants were asked to examine plants within each unidentified pad and judge if an acceptable percentage of the plants were marketable given an average year's climate and the six months of production time. Six months was the amount of time nursery growers polled before the start of the experiment offered as reasonable for obtaining marketable plants in the production scheme used. Canopies of plants in lysimeters were removed at the crown, leaf areas determined using a LICOR 1500 leaf area meter, and stem and leaf dry mass obtained within 1 week after the field day. One week after the field day, all plants within each pad were graded according the Florida Grades and Standards for Nurseries (Gaskalla, 1998). Grades consisted of fancy, No. 1, No. 2, and cull. Only fancy and No. 1 are considered commercially marketable. In early September, canopy average height, widest width and width perpendicular to widest width of 10 plants randomly selected from each pad were measured. Canopies of selected plants were removed at substrate level and dried in a forced-air oven at $65^{\circ} \mathrm{C}$ until a constant dry mass was obtained. Growth indices were calculated for each plant as described above.
Data for each species was analyzed separately. One-way analysis of variance was used to compare cumulative $\mathrm{ET}_{\mathrm{A}}$, irrigated volumes and final canopy variables among irrigation treatments (SAS version 8.0; SAS Institute, Cary, N.C.). With the exception of irrigated volume, for which there was no replication, plant variables were randomized within an irrigation treatment. Regression analysis was used to determine the relation between shoot dry mass and growth indices, and Cumulative $\mathrm{ET}_{\mathrm{A}}$. Regression analysis was also used to determine the relationship between MAD levels and cumulative $\mathrm{ET}_{\mathrm{A}}$ within a species. Data from control regime plants was not included in the regression of MAD level and cumulative $\mathrm{ET}_{\mathrm{A}}$. Where appropriate, means were separated using Fisher's least significant difference method (Snedecor and Cochran, 1980). Growth rates for the variables of plant height, projected canopy surface area and canopy volume (growth index) for plants in lysimeters were determined by linear regression using SAS. Single-degree-of-freedom contrasts were used to compare the slopes for these variables among irrigation regimes where appropriate.

\section{Results and Discussion}

Plant growth And establishing MAD frequencies. LysimETER PLANT GROWTH. Increases in plant height, projected canopy surface area and growth index for plants in lysimeters were linear $(P<0.05)$ within each species and among irrigation regimes. This is similar to the results reported by Welsh and Zajicek (1993) over a much shorter ( $28 \mathrm{~d}$ ) period. Growth rates among irrigation regimes were compared within each species. For sweet viburnum, considered an upright spreading shrub (Gaskalla, 1998), height growth rates (linear slope) for plants grown at 20\% MAD were similar to all other regimes, and greater than those of $80 \%$ MAD plants (Fig. 1A). Height growth rate of control plants was greater $(P<0.05)$ than all MAD regimes except $20 \%$ MAD. Height growth rate for $80 \%$ MAD plants was significantly $(P<0.05)$ slower than all other regimes. Growth rates at $40 \%$ and $60 \%$ MAD were similar $(P>0.05)$. In contrast to height, irrigation regime had no influence $(P>0.05)$ on the rate of increase in canopy projected surface area of the lysimeter plants (Fig. 1B). The decrease in projected canopy area of $80 \%$ MAD plants recorded the last measurement date (day 248) was due to substantial necrosis of branches in late July/early Aug induced by severe water stress. The rate of canopy volume growth (growth index, GI) was greater $(P<0.05)$ in the control and the $20 \%$ MAD regimes than in the other regimes (Fig. 1C). The rate of GI increase of the $80 \%$ MAD plants was significantly slower $(P<0.05)$ than all other regimes and a fourth that of the fastest regimes.

Japanese ligustrum is also considered an upright spreading shrub (Gaskalla, 1998). Irrigation regimes had no effect on height growth rates of japanese ligustrum $(P>0.05$; Fig. $2 \mathrm{~A})$, although height growth rates of $80 \%$ MAD plants were almost half that of the $20 \%$ MAD plants. Rate of projected canopy surface area expansion of $20 \%$ MAD plants was greater $(P<0.05)$ than plants in all other regimes except the $40 \%$ MAD plants (Fig. 2B). Rate of projected canopy surface area expansion of the $40 \%$ MAD plants was also greater than that of the $80 \%$ MAD plants $(P<$ $0.05)$. Rates of GI increases by the $20 \%$ and $40 \%$ MAD regimes plants were greater $(P<0.05)$ than plants in all other regimes (Fig. 2C).

Indian hawthorn, which has a low, mounding growth habit and is considered the most drought tolerant of the species evaluated, demonstrated little effect of MAD treatment on the growth vari- 

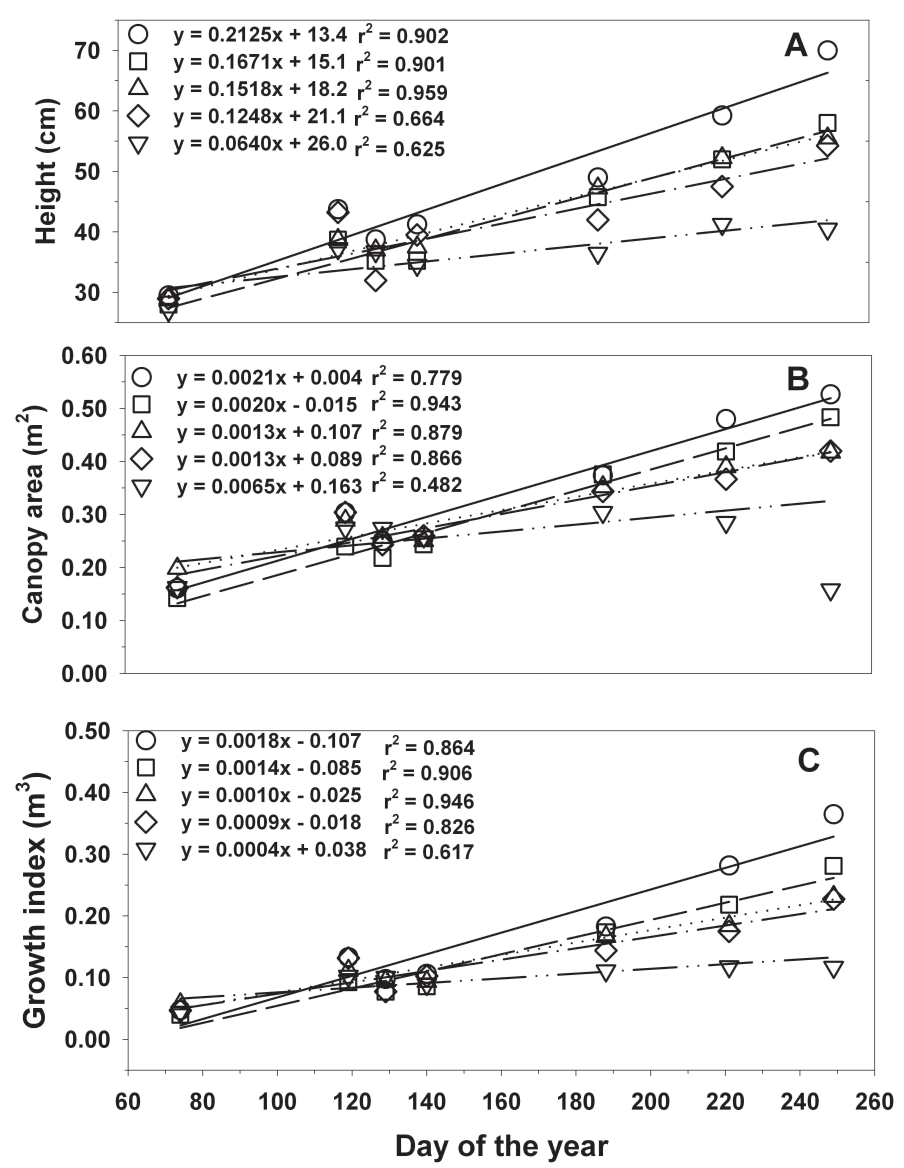

Fig. 1. Growth of second-season sweet viburnum plants in lysimeters after transplanting from 3.8- to 11.4-L containers. Treatments consisted of a daily control irrigation rate of $18 \mathrm{~mm}(\square)$ and irrigation applied at 20\% (४), 40\% $(\Delta), 60 \%(\diamond)$, and $80 \%(\nabla)$ managed allowable deficits (MAD). Height was measured to the average upper buds. Projected canopy area was the product of the widest width times width perpendicular to it. Growth index estimated canopy volume (projected canopy area $\times$ height). Each mean represents two plant replicates.

ables measured. Irrigation regime had no effect on height growth rate $(P>0.05$; Fig. 3A). Rate of projected canopy surface area expansion of 20\% MAD plants was greater $(P<0.05)$ than for plants in all other regimes except the control (Fig. 3B). Rate of projected canopy surface area expansion of plants in the control regime was greater than 60\% MAD plants $(P<0.05)$. The rate of GI increase for $20 \%$ MAD plants was greater $(P<0.05)$ than for plants in all other irrigation regimes (Fig. 3C).

Final haRVest MEASUREMENTs. Final growth indices of sweet viburnum sampled randomly at the end of the experiment were greater $(P>0.05)$ for plants in the control regime and the $20 \%$ and $60 \%$ MAD plants than plants in the $40 \%$ and $80 \%$ MAD regimes (Table 1). This differs from the GI growth rates of lysimeter plants, where increases in GI were similar $(P>0.05)$ between the $40 \%$ and $60 \%$ levels, and significantly less than those of the control and 20\% level (Fig. 1C). These differences are due to contrasting regression derived growth rates to final canopy measurements of different sample subsets and subset sizes. While final mean GI of lysimeter sweet viburnum was generally comparable to the mean of the 10 replications per regime, lysimeter plants in the control and $40 \%$ MAD regimes were larger than their corresponding 10 replication mean. Shoot dry mass was also significantly less for plants randomly harvested from the 40\% MAD regime than those from the $60 \%$ MAD treatments, consistent with GI (Table

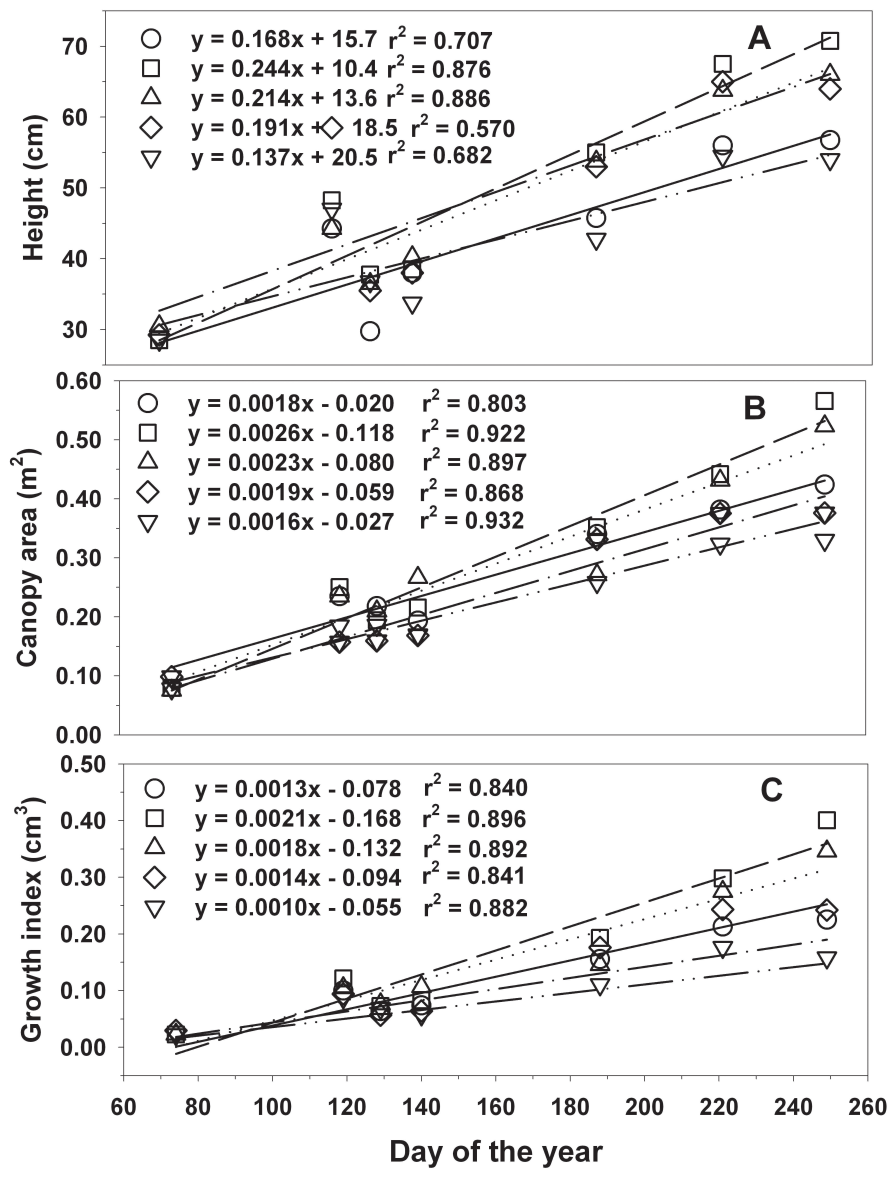

Fig. 2. Growth of second season japanese ligustrum plants in lysimeters after transplanting from 3.8-L to 11.4-L containers. Treatments consisted of a daily control irrigation rate of $18 \mathrm{~mm}(\square)$ and irrigation applied at $20 \%$ ( $\square$ ), $40 \%$ $(\Delta), 60 \%(\diamond)$, and $80 \%(\nabla)$ managed allowable deficits (MAD). Height was measured to the average upper buds. Projected canopy area was the product of the widest width times the width perpendicular to it. Growth index estimated canopy volume (projected canopy area $\times$ height). Each mean represents two plant replicates.

1). Greater mean shoot dry mass was obtained from the $20 \%$ MAD regime compared to all other irrigation treatments for sweet viburnum except the $60 \%$ MAD level.

Japanese ligustrum, randomly sampled at harvest and grown under the $20 \%$ MAD regime had greater final GI $(P<0.05)$ than similar plants in the other regimes (Table 1). Final growth indices of control plants were similar to those of the $40 \%$ MAD plants, with both larger than those in $60 \%$ and $80 \%$ MAD. This contrasts with GI growth rates of lysimeter plants in these regimes. Lysimeter growth rates were similar between $20 \%$ and $40 \%$ MAD regimes, between $40 \%$ and $60 \%$ MAD regimes, and between control, $60 \%$ and $80 \%$ MAD (Fig. 2c). The reason for these differences is the same as put forth for the sweet viburnum. Mean final GI of lysimeter plants in the $20 \%, 40 \%$, and $60 \%$ MAD treatments were greater than those of randomly sampled plants at the end. For shoot dry mass, differences among irrigation regimes were less clear, with greater mass accumulating in japanese ligustrum plants of the $20 \%$ and $40 \%$ MAD regimes, and least amounts in the $60 \%$ and $80 \%$ regimes (Table 1). Differences in shoot dry mass more closely matched the relationships among regimes for lysimeter plant GI.

Lower MAD irrigation resulted in significantly greater canopy volumes (growth index) and dry mass than higher MAD regimes for indian hawthorn sampled at the end of the experiment (Table 

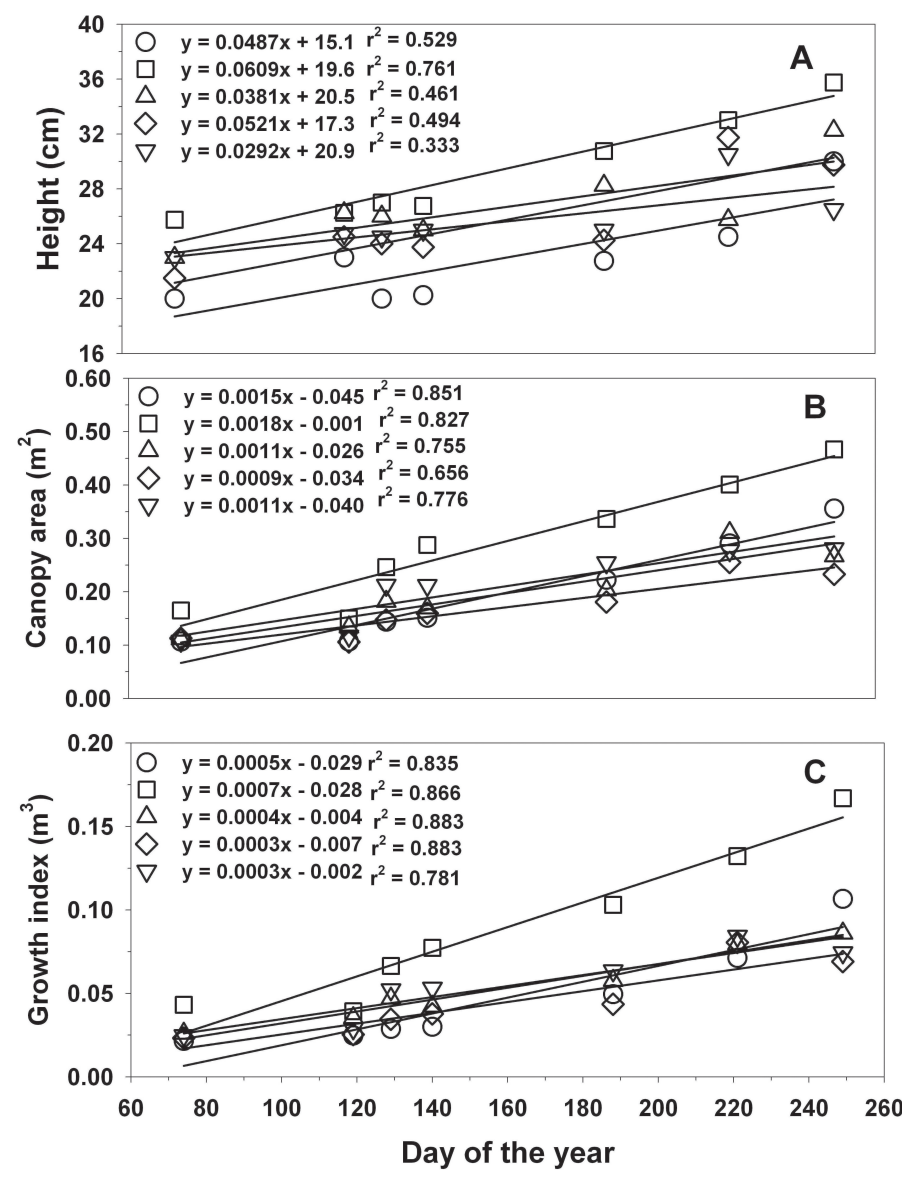

Fig. 3. Growth of second season indian hawthorn plants in lysimeters after transplanting from 3.8- to 11.4-L containers. Treatments consisted of a daily control irrigation rate of $18 \mathrm{~mm}(\square)$ and irrigation applied at $20 \%$ ( $\square$ ), $40 \%$ $(\Delta), 60 \%(\diamond)$ and $80 \%(\nabla)$ managed allowable deficits (MAD). Height was measured to the average upper buds. Projected canopy area was the product of the widest width times the width perpendicular to it. Growth index estimated canopy volume (projected canopy area $\times$ height). Each mean represents two plant replicates.

Table 1. Canopy growth index and shoot dry mass of three species after 6.5 months of growth in 11.4-L containers under different managed allowable deficit (MAD) irrigation regimes. Plants were initially transplanted from 3.8-L containers.

\begin{tabular}{|c|c|c|c|c|c|c|}
\hline \multirow[b]{2}{*}{ MAD } & \multicolumn{2}{|c|}{$\begin{array}{c}\text { Sweet } \\
\text { viburnum }\end{array}$} & \multicolumn{2}{|c|}{$\begin{array}{c}\text { Japanese } \\
\text { ligustrum }\end{array}$} & \multicolumn{2}{|c|}{$\begin{array}{c}\text { Indian } \\
\text { hawthorn }\end{array}$} \\
\hline & $\overline{\mathrm{GI}^{\mathrm{z}}\left(\mathrm{m}^{3}\right)}$ & $\overline{\text { DMy }^{y}(\mathrm{~g})}$ & $\overline{\mathrm{GI}}\left(\mathrm{m}^{3}\right)$ & $\overline{\mathrm{DM}(\mathrm{g})}$ & $\overline{\mathrm{GI}\left(\mathrm{m}^{3}\right)}$ & DM (g) \\
\hline Control $^{x}$ & $0.233 \mathrm{a}^{\mathrm{w}}$ & $142 \mathrm{bc}$ & $0.248 \mathrm{~b}$ & $171 \mathrm{~b}$ & $0.083 \mathrm{a}$ & $167 \mathrm{~b}$ \\
\hline $20 \%{ }^{v}$ & $0.264 \mathrm{a}$ & $187 \mathrm{a}$ & $0.330 \mathrm{a}$ & $210 \mathrm{a}$ & $0.088 \mathrm{a}$ & $196 \mathrm{a}$ \\
\hline $40 \%$ & $0.167 \mathrm{~b}$ & $131 \mathrm{c}$ & $0.235 \mathrm{~b}$ & $188 \mathrm{ab}$ & $0.083 \mathrm{a}$ & $177 \mathrm{ab}$ \\
\hline $60 \%$ & $0.224 \mathrm{a}$ & $162 \mathrm{ab}$ & $0.180 \mathrm{c}$ & $164 \mathrm{bc}$ & $0.054 \mathrm{~b}$ & $117 \mathrm{c}$ \\
\hline $80 \%$ & $0.102 \mathrm{c}$ & $88 \mathrm{~d}$ & $0.143 \mathrm{c}$ & $135 \mathrm{c}$ & $0.061 \mathrm{~b}$ & $132 \mathrm{c}$ \\
\hline
\end{tabular}

${ }^{\mathrm{z}}$ Growth index, calculated at widest width times perpendicular width times average height in $\mathrm{m}^{3}$.

yShoot dry mass.

xPlants irrigated at $18 \mathrm{~mm}$ daily independent of rainfall.

wMeans with the same letter within columns are not significantly different $(P>0.05)$ based on Fisher protected LSD $(\mathrm{n}=10)$.

${ }^{v}$ Minimum percentage of plant available moisture to which containers were allow to dry to before irrigation occurred.
1). In contrast, GI growth rates of lysimeter plants were similar over the $40 \%$ to $80 \%$ MAD range and control, with those from the $20 \%$ MAD being significantly $(P<0.05)$ greater (Fig. 3C). The final GI of the lysimeter plants were comparable to the randomly sampled plants at the end, except for lysimeter plants of the $20 \%$ MAD regime. These plants were substantially larger at the end of the experiment than the 10 sample replications. Like japanese ligustrum, plants under the control irrigation treatment fell mid-way between the extremes (Table 1).

QUALITATIVE EVALUATIONS BY GROWERS. The majority of growers judged sweet viburnum grown in the control and $20 \%$ MAD, japanese ligustrum grown in $20 \%$ MAD, and indian hawthorn grown in the control, $20 \%$ and $40 \%$ MAD regimes to be of acceptable marketable size and quality (Table 2 ). This contrasts with evaluations based on the Florida Grades and Standards for Nursery Plants (Gaskalla, 1998) conducted 1 week later (Table 3). A 90\% marketability rate was considered the minimum by nurseries in central Florida (unpublished data). Marketable plants were those rated as \#1 or Fancy. Plants rated as \#2 or culls were not counted as marketable. Based on these guidelines, all but the $80 \%$ MAD regime for sweet viburnum produced $89 \%$ or more of the plants within the top highest grades (Table 3). For japanese ligustrum, the $60 \%$ MAD was of questionable success, while lower MAD regimes and the daily control were acceptable (Table 3). All irrigation regimes produced acceptable size and quality plants of indian hawthorn (Table 3).

Based on the grower survey, final growth measurements and plant marketability, maximum MAD's were concluded to be $20 \%$ for sweet viburnum and $40 \%$ for indian hawthorn. MAD levels greater than these were associated with significant $(P<0.05)$ declines in canopy size and grower preference. Determining an acceptable maximum MAD for japanese ligustrum was more

Table 2. Percentage of responses from the grower field evaluation which judged that a commercially acceptable percentage of the plants within each managed allowable deficit treatment were of at least average marketable quality.

\begin{tabular}{lccccc}
\hline & \multicolumn{5}{c}{ Managed allowable deficit (MAD) } \\
\cline { 2 - 6 } Species & Control $^{\mathrm{z}}$ & $20^{\mathrm{y}}(\%)$ & $40(\%)$ & $60(\%)$ & $80(\%)$ \\
\hline Sweet viburnum & $97^{\mathrm{x}}$ & 80 & 3 & 30 & 0 \\
Japanese ligustrum & 43 & 73 & 27 & 7 & 7 \\
Indian hawthorn & 90 & 90 & 67 & 7 & 30
\end{tabular}

zPlants irrigated at $18 \mathrm{~mm}$ daily independent of rainfall.

yMinimum percent of plant available moisture containers were allowed to dry to before irrigation occurred.

xPercentage based on 30 responses.

Table 3. Percentage of plants within each species and irrigation treatment which were ranked as commercially acceptable size based the Florida Grades and Standards for Nursery Crops (Gaskalla, 1998) at the end of the experimental period.

\begin{tabular}{lccccc}
\hline & \multicolumn{5}{c}{ Managed allowable deficit (MAD) } \\
\cline { 2 - 6 } Species & Control $^{\mathrm{z}}$ & $20^{\mathrm{y}}(\%)$ & $40(\%)$ & $60(\%)$ & $80(\%)$ \\
\hline Sweet viburnum & $100^{\mathrm{x}}$ & 100 & 89 & 90 & 14 \\
Japanese ligustrum & 98 & 97 & 97 & 83 & 55 \\
Indian hawthorn & 100 & 97 & 97 & 94 & 95 \\
\hline
\end{tabular}

zPlants irrigated at $18 \mathrm{~mm}$ daily independent of rainfall.

yMinimum percent of plant available moisture containers were allowed to dry to before irrigation occurred.

xPercentage based on 65 plants per treatment. 
difficult to establish. Based on Grades and Standards (Table 3) and canopy variables for random plants (Table 1), a 40\% MAD would be acceptable. However grower evaluations (Table 2) only support a maximum of a $20 \%$ MAD. Hence as a compromise, a 30\% MAD is proposed. In deriving this conclusion, greatest consideration was given to the final growth measurements (Table 1). Thus the MAD for sweet viburnum and japanese ligustrum are comparable to the $25 \%$ MAD proposed by Welsh and Zajicek (1993) for Photinia $\times$ fraseri (red tip photina).

Maximum MAD proposed above for each species did not correspond to the grading by plant size based on Florida Grades and Standards (Table 3). Greater than $90 \%$ of the plants grown at higher levels of MAD than the proposed maximum MAD were still considered marketable size, even though the mean canopy dimensions were significantly $(P<0.05)$ smaller. Grading was based principally on average width being equal to or greater than a preset fraction of plant height, assuming a minimum height had been achieved. For sweet viburnum and japanese ligustrum, average width needed to be two-thirds plant height to be considered marketable quality (\#1). For indian hawthorn, average width needed to be equal to plant height (Gaskalla, 1998). Poorly branched, thin canopies were reduced one grade lower than the guidelines based on canopy size, as required in the regulations.

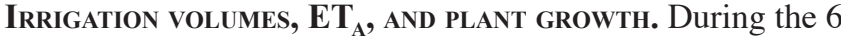
months of growth, rainfall exceeded the 30 year average by $\approx 25$ $\mathrm{cm}$. However, rainfall in the Spring was below average, with most of the excess falling in late May, late June, and late July through August (data not shown). Initially after transplanting, plant available water was consistent across irrigation regimes and species, averaging $1.1 \mathrm{~L}$. At the second determination in mid-May, plant available water was still consistent across irrigation regimes and species, averaging $3.5 \mathrm{~L}$ per container.

IRRIGATION AMOUNTS. Plants in control regimes received an average of $18 \mathrm{~mm}$ of irrigation daily during the $177 \mathrm{~d}$ of this experiment, for total depths of $3.48 \mathrm{~m}$ (Fig. 4). This exceeded the average daily rate of $12.5 \mathrm{~mm}$ applied by nurseries in Alabama, but was within the range of irrigation rates reported (Fare et al., 1992). Because irrigation of these plants was controlled by a time clock with no rain shut-off device, rainfall during the experiment contributed an additional $0.905 \mathrm{~m}$ to each container. This increased total water applied above the canopy within the projected surface area of an average container in the control regime to $4.4 \mathrm{~m}$ (Fig. 4). Irrigation of plants in the MAD regimes was programmed to incorporate effective rainfall that occurred prior to midnight. Effective rainfall was defined as rainfall which resulted in an increase in container water to the point of substrate saturation and drainage. During the experimental period, nearly all rainfall resulted from thunderstorms that typically began after mid-day and ended before midnight. Hence, most rainfall contributed to reductions in irrigation frequency of the MAD treatments. Irrigation events declined with increasing MAD levels for each species (Table 4), corresponding to decreasing irrigation amounts (Fig. 4). Over the 6-month period, 43 rain events occurred with accumulation of $6 \mathrm{~mm}$ or greater. However, despite this accounting for effective rainfall, irrigation amounts at all MAD levels except at $80 \%$ exceeded that of the daily irrigated control for sweet viburnum and japanese ligustrum (Fig. 4A and 4B, respectively). Indian hawthorn, the species representative of low irrigation requirements, also received irrigation amounts in excess of the control except at the $60 \%$ and $80 \%$ MAD levels (Fig 4C).

Excessive amounts of irrigation for the MAD regimens, relative to the control regimes (Fig. 4), was a result of the rigidity

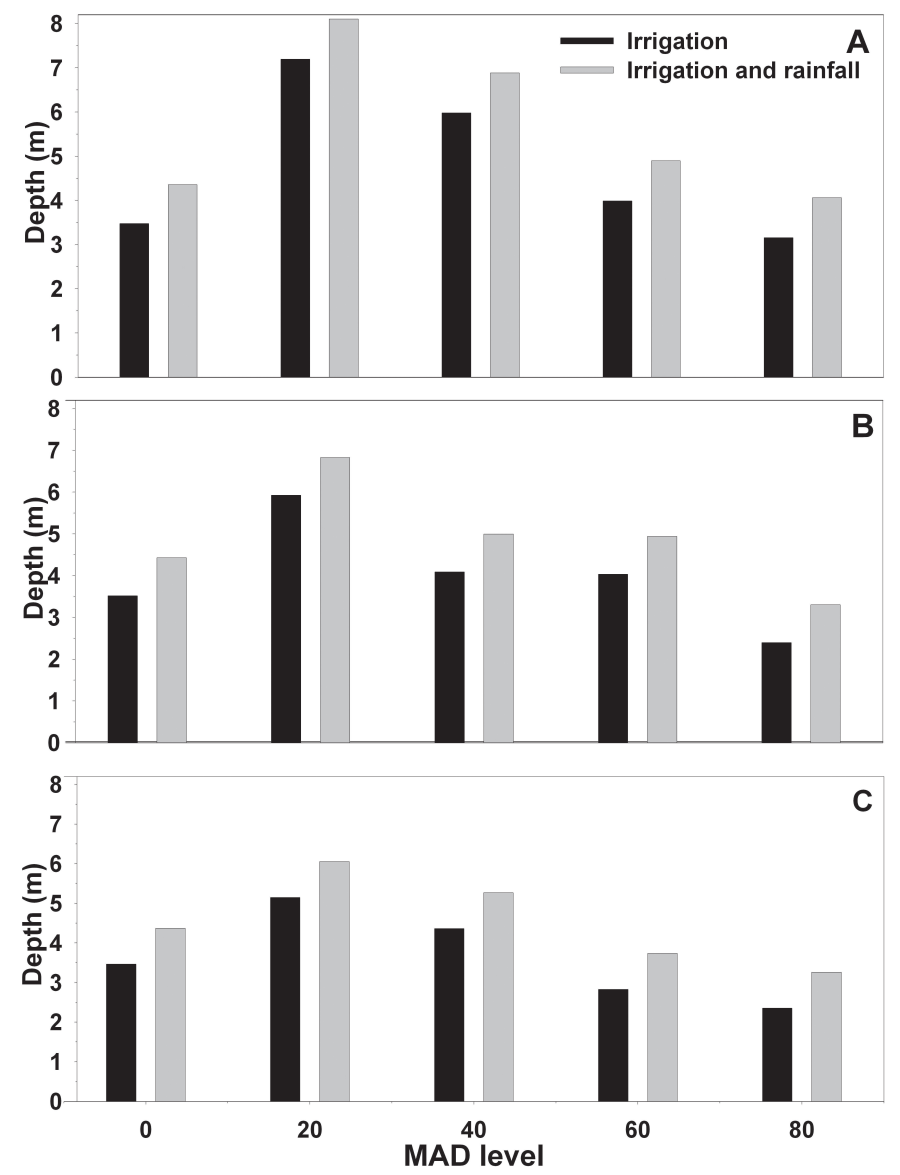

Fig. 4. Depth of water falling above a canopy during the 6 months of production time. Supplemental irrigation was applied overhead using impact sprinklers. Rainfall was measured using a calibrated tipping bucket rain gauge on site. Depth is by managed allowable deficits (MAD) irrigation regime for (A) sweet viburnum, (B) japanese ligustrum, and (C) indian hawthorn. The control level (0) corresponds to a fixed regime of $18 \mathrm{~mm}$ daily. The other values correspond to the minimum percentage of MAD required before irrigation occurred. Each mean is a single replicate.

Table 4. Number of irrigation events over the 6-month production period for each species and irrigation regime. Maximum possible number of irrigation events would have been 177. Irrigation failure in July resulted in two to four additional hand irrigations not recorded for in the table.

\begin{tabular}{lccccc}
\hline & \multicolumn{5}{c}{ Managed allowable deficit (MAD) } \\
\cline { 2 - 6 } Species & Control $^{\mathrm{z}}$ & $20^{\mathrm{y}}(\%)$ & $40(\%)$ & $60(\%)$ & $80(\%)$ \\
\hline Sweet viburnum & $171^{\mathrm{x}}$ & 93 & 54 & 39 & 24 \\
Japanese ligustrum & 171 & 70 & 43 & 39 & 22 \\
Indian hawthorn & 171 & 70 & 42 & 27 & 21
\end{tabular}

${ }^{2}$ Plants irrigated at $18 \mathrm{~mm}$ daily independent of rainfall.

yMinimum percent of plant available moisture containers were allowed to dry to before irrigation occurred.

xRepresents single production pad replication.

of the irrigation subroutine programmed into the data logger. Frequently, lysimeter plants would transpire enough to trigger an irrigation event that night only to capture sufficient rainfall prior to $2200 \mathrm{~h}$ to raise the mass above the threshold for initiating the event, but not re-saturating the substrate. The following day, often plants would begin near their respective MAD threshold and may have transpired up to an additional $30 \%$ of the total plant available water in the container (data not shown). Rainfall may or may not have delayed irrigation another day, but rarely 
re-saturated the substrate. When irrigation occurred, substrates were commonly drier than the desired MAD level. At the $80 \%$ MAD level, substrates frequently retracted from the container side wall from dehydration prior to irrigation. The irrigation subroutine was programmed to apply irrigation until container capacity returned to near $100 \%$. In the preliminary experiment, mass increased in a decaying exponential curve with duration of overhead irrigation (data not shown). After $3 \mathrm{~h}$, a moderately dry plant/container system continued to slowly increase in mass with an application rate of $19 \mathrm{~mm} \cdot \mathrm{h}^{-1}$ (data not shown). The $10 \mathrm{~g}$ per $10 \mathrm{~min}$ rate occurred when $\approx 98 \%$ of the total weight increase over a 3 -h period had been achieved. The objective of the irrigation subroutine was to return the container system to near container capacity. It was unanticipated that such irrigation volumes would be required.

Cumulative $\mathbf{E T}_{\mathrm{A}}$. Cumulative $\mathrm{ET}_{\mathrm{A}}$ volume declined linearly with increases in MAD for all species (Table 5). Declines in cumulative $\mathrm{ET}_{\mathrm{A}}$ as MAD levels increased were comparable $(P>$ 0.05 ) among species based on single-degree-of-freedom contrasts, although intercepts were significantly different $(P<0.05)$. With exception of sweet viburnum, mean cumulative $\mathrm{ET}_{\mathrm{A}}$ volumes of the control treatments were similar to $60 \%$ MAD plants. Although sweet viburnum were indicated by growers as having the highest irrigation requirement, cumulative $\mathrm{ET}_{\mathrm{A}}$ were similar between sweet viburnum and japanese ligustrum over the range of MAD levels. Cumulative $\mathrm{ET}_{\mathrm{A}}$ for the species reported here were 1.5- to 3-fold larger than those reported by Knox (1989) in 3.8-L containers over a 1-year span. Cumulative $\mathrm{ET}_{\mathrm{A}}$ for his species ranged from $38 \mathrm{~L}$ for red tip photinia to $50 \mathrm{~L}$ for 'Teton' pyracantha (Pyracantha coccinea M. Roemer.). Based on the methodology, plants in Knox's (1998) research likely were maintained comparable to the $20 \%$ to $40 \%$ MAD regimes used here. Cumulative $\mathrm{ET}_{\mathrm{A}}$ for japanese ligustrum grown under well-watered conditions in 7.6-L containers, while still substantially less (18 L over 70 d; Steinberg et al., 1991), was much closer to the values reported here. Difference between cumulative $\mathrm{ET}_{\mathrm{A}}$ reported here, and those of Steinberg et al. (1991) are most likely due to differences in plant size, which in the author's experience is nonlinear relative to container size. These large differences in cumulative $\mathrm{ET}_{\mathrm{A}}$ reported here underscore the importance of using separate irrigation zones for different size containers and different size plants within the same container size for water conservation.

ET $_{\mathbf{A}}$ AND WATER APPLIED. For japanese ligustrum and indian hawthorn, the percentage of the potential water volume (irrigation + rainfall) received by a container to that evapotranspired was similar $(P>0.05)$ among control and all MAD irrigation regimes (Table 6). Mean percentage was $\approx 48 \%$ for japanese ligustrum and $38 \%$ indian hawthorn, respectively. Similarly, comparable percentages were calculated among MAD regimes for sweet viburnum. For all species, there was a trend for increasing percentage of water evapotranspired with increasing MAD level. The high conversion of water received to $\mathrm{ET}_{\mathrm{A}}$ of $78 \%$ for the sweet viburnum control regime is exceptional compared to the other values in this table. While seemingly in error, its validity could not be disputed and may be indicative of possible apparent conversion efficiencies. Actual percentage of water received that evapotranspired by these plants would probably be higher than indicated in Table 6. For container plants growing in close proximity such that canopies overlap (closed-canopy systems), a significant portion of overhead sprinkler irrigation that fell above a plant canopy could have been channeled to outside the substrate surface area and fell between containers (Beeson and Yeager, 2003). The greater the amount of canopy overlap, the lower the percentage of sprinkler irrigation reaching the container surface. In this experiment, such canopy channeling would have begun about half way through the production period for the sweet viburnum and japanese ligustrum at the container spacing used (Figs. 1B and 2B). Shedding of water away from the center of a plant would have decreased the amount reaching the container surface, thus increasing the conversion efficiency.

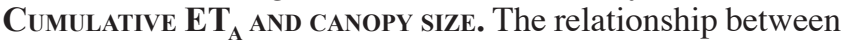
cumulative $\mathrm{ET}_{\mathrm{A}}$ and canopy dry mass was linear $(P<0.01)$ and highly correlated for each species (Fig. 5). These relationships were drawn from data across all irrigation regimes. Thus there is a direct relationship between plant $\mathrm{ET}_{\mathrm{A}}$ and shoot dry mass accumulation. This was shown previously for three tree species (Devitt and Neuman, 1994) and numerous herbaceous plants (Allison et al., 1958; Arkey, 1963), and is a direct result of the tight linkage between photosynthetic rates and transpiration (Salisbury and Ross, 1978). The rate of shoot dry mass accumulation was similar between japanese ligustrum and indian hawthorn $(P>$ 0.05 ). Both gained $\approx 2.9 \mathrm{~g}$ of shoot dry mass per liter of water evapotranspired. Dry mass gain per liter $\mathrm{ET}_{\mathrm{A}}$ for sweet viburnum was $\approx 72 \%$ of that of the other two species. Although net shoot dry mass accumulation could not be calculated because initial shoot dry mass was not recorded, the rate relationship between dry mass cumulative $\mathrm{ET}_{\mathrm{A}}$ would not change, since a constant dry mass would have been subtracted from each plant within a species.

Relationships between cumulative $\mathrm{ET}_{\mathrm{A}}$ and the final growth index of each lysimeter plant was also linear $(P<0.01)$ and highly correlated within a species (Fig. 6). Although sweet viburnum and japanese ligustrum both started and finished at comparable

Table 5. Mean cumulative actual evapotranspiration $\left[\mathrm{ET}_{\mathrm{A}}\right.$ (liters)] of each species grown at each irrigation regime over a 6-month production period. Plants were transplanted from 3.8-L container into an 11.4-L container and grown for 6 months. Regression equations relating managed allowable deficit to cumulative $\mathrm{ET}_{\mathrm{A}}$ did not include data from control plants.

\begin{tabular}{lcccccc}
\hline & \multicolumn{5}{c}{ Managed allowable deficit (MAD) } \\
\cline { 2 - 6 } Sontrol & $20 \mathrm{y}$ & \multicolumn{1}{c}{40} & \multicolumn{1}{c}{60} & 80 & \\
Species & $(\mathrm{L})$ & \multicolumn{1}{c}{$(\mathrm{L})$} & \multicolumn{1}{c}{$(\mathrm{L})$} & \multicolumn{1}{c}{$(\mathrm{L})$} & \multicolumn{1}{c}{$(\mathrm{L})$} & Regression equations \\
\hline Sweet viburnum & $164.5^{\mathrm{x}}$ & 124.8 & 115.0 & 102.3 & 82.6 & $\mathrm{ET}_{\mathrm{A}}=141.5-0.708(\mathrm{MAD})(0.790)^{\mathrm{w}}$ \\
Japanese ligustrum & 106.8 & 137.3 & 111.7 & 107.8 & 88.1 & $\mathrm{ET}_{\mathrm{A}}=149.7-0.773(\mathrm{MAD})(0.894)$ \\
Indian hawthorn & 77.6 & 104.1 & 85.7 & 71.1 & 68.3 & $\mathrm{ET}_{\mathrm{A}}=112.5-0.606(\mathrm{MAD})(0.871)$ \\
\hline
\end{tabular}

${ }^{2}$ Plants irrigated at $18 \mathrm{~mm}$ daily independent of rainfall.

yMinimum percent of plant available moisture containers were allowed to dry to before irrigation occurred.

xMean of two plant replications.

${ }^{\mathrm{w}}$ Correlation coefficient $\left(r^{2}\right)$. 
Table 6. Percentage of water falling above a plant canopy within a cylinder of the container diameter (overhead irrigation and rainfall) that was evapotranspired at each irrigation regime by species.

\begin{tabular}{lccccc}
\hline \multirow{2}{*}{ Species } & \multicolumn{5}{c}{ Managed allowable deficit (MAD) } \\
\cline { 2 - 6 } Control $^{\mathrm{z}}$ & $20 \mathrm{y}(\%)$ & $40(\%)$ & $60(\%)$ & $80(\%)$ \\
\hline Sweet viburnum & $78.3^{\mathrm{x}}$ & 31.9 & 34.6 & 43.3 & 42.2 \\
Japanese ligustrum & 50.1 & 41.7 & 46.4 & 45.3 & 55.4 \\
Indian hawthorn & 36.9 & 35.7 & 33.8 & 39.5 & 43.4
\end{tabular}

zPlants irrigated at $18 \mathrm{~mm}$ daily independent of rainfall.

yMinimum percent of plant available moisture containers were allowed to dry to before irrigation occurred.

${ }^{x}$ Mean of two plant replications.

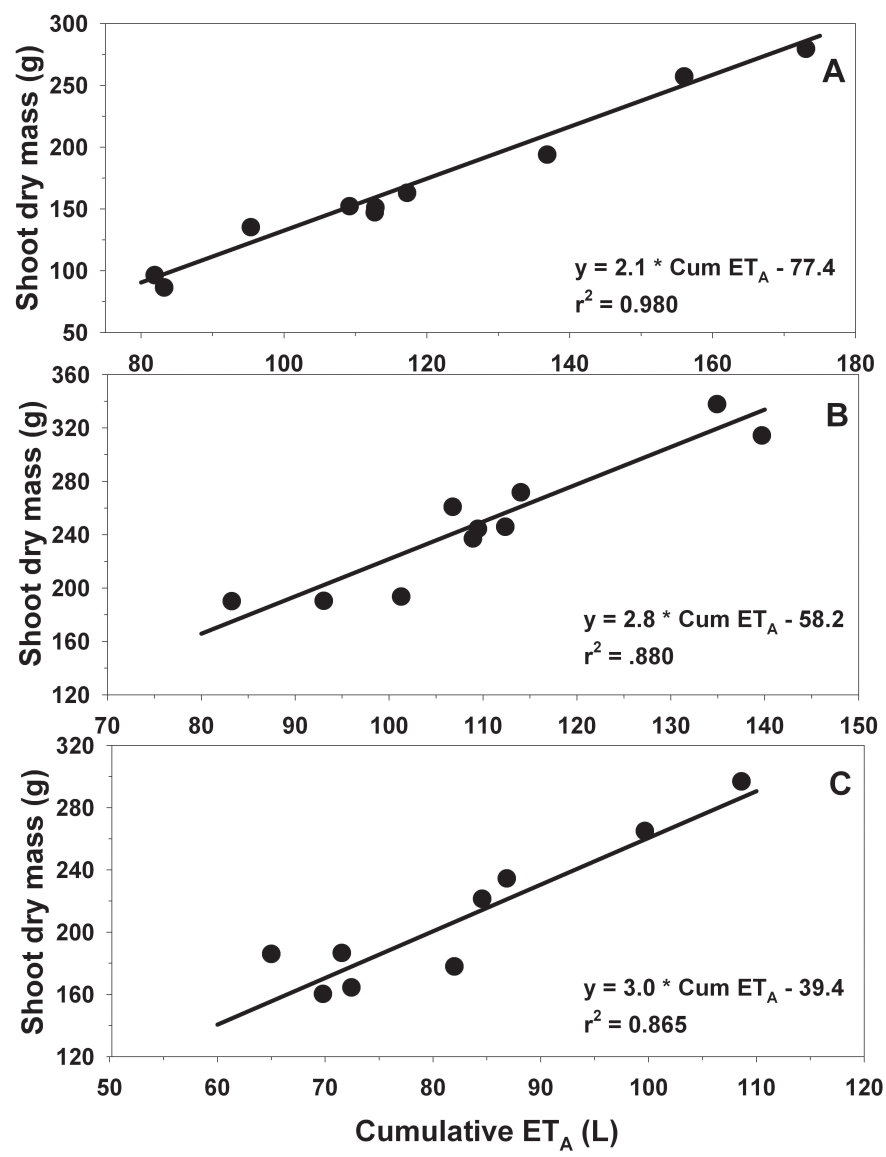

Fig. 5. Relationship between cumulative evapotranspiration (Cum. ET $)$ and shoot dry mass of lysimeter plants for (A) sweet viburnum, (B) japanese ligustrum, and $(\mathbf{C})$ indian hawthorn during the 6-month production period. Each point represents a single plant replicate. Each graph is the aggregation of all lysimeter plants across the five irrigation regimes. One outlying point for indian hawthorn was not included in the regression analysis.

GI, the rate of increase in canopy volume per liter of cumulative $\mathrm{ET}_{\mathrm{A}}$ for the japanese ligustrum was nearly double that of the sweet viburnum (Fig. 6). In terms of nursery plant production and irrigation, this indicates that for plants to obtain some specified size, there is a semi-absolute volume of cumulative $\mathrm{ET}_{\mathrm{A}}$ that must occur. As exemplified in differences between indian hawthorn and the other two species, this minimum cumulative $\mathrm{ET}_{\mathrm{A}}$ will likely be species specific or specific to a group of species, as seen for the sweet viburnum and japanese ligustrum (Table 5). Thus, restrictive irrigation regimes that limit daily $\mathrm{ET}_{\mathrm{A}}$ will only extend the time required for plant production, such as in the
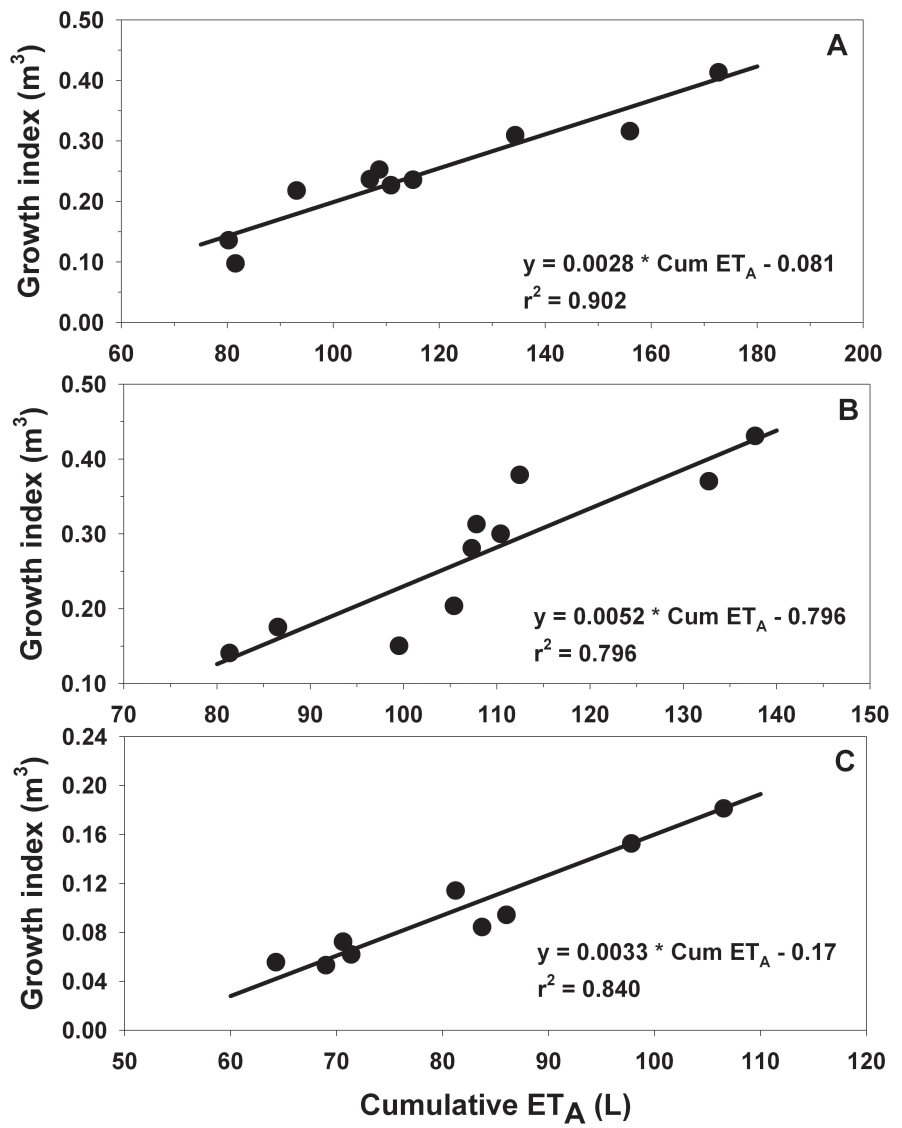

Fig. 6. Relationship between cumulative evapotranspiration (Cum. ET A $_{A}$ and shoot growth index of lysimeter plants for (A) sweet viburnum, (B) japanese ligustrum, and $(\mathbf{C})$ indian hawthorn during the 6-month production period. Each point represents a single plant replicate. Each graph is the aggregation of all lysimeter plants across the five irrigation regimes. One outlying point for indian hawthorn was not included in the regression analysis.

higher MAD treatments used here. While restrictive supplemental irrigation may reduce annual irrigation volumes, the volume of supplemental irrigation required per crop would vary mainly because of differences in rainfall, not cumulative $\mathrm{ET}_{\mathrm{A}}$. If $\mathrm{ET}_{\mathrm{A}}{ }^{-}$ restricting irrigation extends production into periods of lower rain fall or an additional winter dormancy period, the amount of supplemental irrigation per crop may actually increase, compared to less restrictive irrigation regimes.

\section{Literature Cited}

Allen, R.G. 2000. Ref-ET: Reference evapotranspiration calculation software. Univ. of Idaho, Boise.

Allison, F.E., E.M. Roller, and W.A. Raney. 1958. Relationship between evapotranspiration and yield of crops grown in lysimeters receiving natural rainfall. Agron. J. 50:253-259.

Arkey, R.J. 1963. Relationships between plant growth and transpiration. Hilgardia 34:559-584.

Beeson, R.C., Jr. 1992. Restricting overhead irrigation to dawn limits growth in container-grown woody ornamentals. HortScience 27:966-999.

Beeson, R.C., Jr., and G.W. Knox. 1991. Analysis of efficiency of overhead irrigation in container production. HortScience 26:848-850.

Beeson, R.C., Jr., and J.J. Haydu. 1995. Cyclic microirrigation in container-grown landscape plants improves plant growth and water conservation. J. Environ. Hort. 13:6-11. 
Beeson, R.C., Jr., M.A. Arnold, T.E. Bilderback, B. Bolusky, S. Chandler, H.M. Gramling, J.D. Lea-Cox, J.R. Harris, P.J. Klinger, H.M. Mathers, J.M. Ruter, and T.H. Yeager. 2004. Strategic vision of container nursery irrigation in the next ten years. J. Environ. Hort. 22:113-115.

Beeson, R.C., Jr., and T.H. Yeager. 2003. Plant canopy affects sprinkler irrigation application efficiency of container-grown ornamentals. HortScience 38:1373-1377.

Devitt, D.A., R.L. Morris, and D.S. Neuman. 1994. Evapotranspiration and growth response of three woody ornammental species placed under varying irrigation regimes. J. Amer. Soc. Hort. Sci. 119:452-457.

Fare, D.C., C. H. Gilliam, and G.J. Keever. 1992. Monitoring irrigation at container nurseries. HortTechnology 2:75-78.

Gaskalla, R. 1998. Grades and standards for nursery plants, $2^{\text {nd }}$ ed. Florida Dept. of Agr. and Consumer Services, Tallahassee.

Halevy, A.H. 1972. Water stress and the timing of irrigation. HortScience 7:113-116.

Haman, D.Z., A. Smaljstra, and D. Pitt. 1996. Uniformity of sprinkler and microirrigation systems for nurseries. Fla. Coop. Ext. Serv. Bul. 321.

Hargreaves, G.H. and Z.A. Samani. 1982. Estimating potential evapotranspiration. J. Irr. Drainage Eng. 108:225-230.

Haydu, J.J. and R.C. Beeson, Jr. 1997. Economic feasibility of micro-irrigating container-grown landscape plants. J. Environ. Hort. 15:23-29.

Keever, G.J. and G.S. Cobb. 1985. Irrigation scheduling effects on container media and canopy temperature and growth of 'Hershey's Red' azalea. HortScience 20:921-923.

Knox, G.W. 1989. Water use and average growth index of five spe- cies of container grown woody landscape plants. J. Environ. Hort. 7:136-139.

Ruter, J.M. 1998. Pot-in-pot production and cyclic irrigation influence growth and irrigation efficiency of 'Okame' cherries. J. Environ. Hort. 16:159-162.

Salisbury, F.B and C.W. Ross. 1978. Plant physiology, $2^{\text {nd }}$ ed. Wadsworth, Belmont, Calif.

Snedecor, G.W. and W.G. Cochran, 1980 Statistical methods, $7^{\text {th }}$ ed. Iowa State University Press, Ames.

Standards Australia. 1989. Australian standard, potting mixes. AS37431989. Standards Australia, North Sydney, Australia.

Steinberg, S.L., J.M. Zajicek, and M.J. McFarland. 1991. Short-term effect of uniconazole on the water relations and growth of Ligustrum. J. Amer. Soc. Hort. Sci. 116:460-464.

Timmer, V.R. and G. Armstrong. 1989. Growth and nutrition of containerized Pinus resinosa seedlings at varying moisture regimes. New For. 3:171-180.

Tyler, H.H., S.L. Warren, and T.E. Bilderback. 1996. Cyclic irrigation increases irrigation application efficiency and decreases ammonium losses. J. Environ. Hort. 14:194-198.

Weatherspoon, D.M. and C.C. Harrell. 1980. Evaluation of drip irrigation for container production of woody landscape plants. HortScience 15:488-489.

Welsh, D.F. and J.M. Zajicek. 1993. A model for irrigation scheduling in container-grown nursery crops utilizing management allowed deficits (MAD). J. Environ. Hort. 11:115-118.

Whitesides, R. 1989. El Modeno Gardens: Innovative solutions to California's irrigation runoff restrictions. Grower Talks 59(2):28-32. 